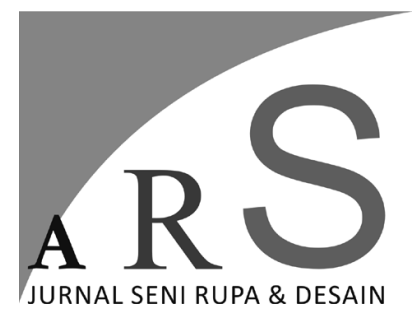

Volume 23 Nomor 3 September - Desember 2020

\section{BUKU ILUSTRASI POLA ASUH YANG TEPAT UNTUK MENUMBUHKAN EMOSI POSITIF ANAK}

\author{
Masnuna, Nur Latifatuz Zakiyah
}
Program Studi Desain Komunikasi Visual, Fakultas Arsitektur dan Desain, Universitas Pembangunan Nasional "Veteran" Jawa Timur
Jl. Raya Rungkut Madya, Gunung Anyar, Surabaya, 60294
Telp./ Fax. (031) 782087
E-mail:masnuna.dkv@upnjatim.ac.id/nur.zaqiyah63@gmail.com

\begin{abstract}
ABSTRAK
Pola asuh yang tepat penting untuk proses perkembangan anak, hal ini bertujan agar anak tidak tumbuh dengan emosi negatif. Namun, pada kenyataannya banyak orang tua yang tidak mengetahui akan pentignya pola asuh yang yang tepat sehingga orang tua banyak melakukan pola asuh yang salah seperti menggunakan kekerasan verbal ataupun fisik. Memberikan solusi dan edukasi kepada orang tua muda dan calon orang tua mengenai masalah ini adalah tujuan dari perancangan agar tidak terjadi kekerasan terhadap anak yang menyebabkan anak tumbuh dengan emosi negatif. Maka, terdapat dua tahapan metode yang dilakukan, yaitu tahap persiapan dan tahap penciptaan. Tahap persiapan meliputi pengumpulan data, analisis data, sintesis, dan penentuan objek perancangan. Sedangkan tahap penciptaan meliputi pra produksi, produksi dan pasca produksi. Dengan menggunakan metode tersebut akan menghasilkan konsep desain dengan keyword "Kunci Mendidik Anak Emas", yaitu solusi bagi orang tua dalam mengasuh anak kesayangan pada masa keemasan agar tumbuh menjadi pribadi yang lebih baik. Dengan adanya keyword tersebut dapat dijadikan sebagai acuan dalam pembuatan buku ilustrasi tentang pola asuh yang tepat. Media buku ilustasi dirancang sebagai media bantu dan pendamping bagi orang tua agar anak tumbuh dengan emosi yang positif serta sebagai kontrol bagi orang tua agar menghindari perilaku-perilaku negatif dalam mendidik anak.
\end{abstract}

Kata Kunci: pola asuh, emosi, buku, anak

\begin{abstract}
The Illustration Book About Proper Parenting To Growing Positive Emotions For Children. Proper parenting is important for the child's development process, it is raining so that children don't grow up with negative emotions. However, in reality many parents do not know the importance of proper parenting so many parents do wrong parenting like using verbal or physical violence. Providing solutions and education to young parents and prospective parents about this problem is the purpose of design so that there is no child abuse that causes children to grow with negative emotions. So, there are two stages of the method, there is the preparation phase and the creation phase. The preparation phase includes data collection, data analysis, synthesis, and determination of design objects. While the stages of creation include pre-production, production and post-production. Using this method will produce a design concept with the keyword "The Key to Educating Golden Children" which is a solution for parents in caring for their favorite children in the golden age so that they grow into a better person. With these keywords can be used as a reference in making illustrated books about proper parenting. Illustration book media is designed as a media for assisting and accompanying parents so that children grow with positive emotions and as a control for parents to avoid negative behaviors in educating children.
\end{abstract}

Keywords : parenting, emotion, book, child 


\section{Pendahuluan}

Seluruh cara perlakuan orang tua terhadap anaknya disebut dengan pola asuh. Orang tua harus membangun pola asuh yang baik sehingga tercipta pula hubungan yang baik dengan anak. Anak usia dini merupakan golongan yang berada dalam proses perkembangan unik (Amrillah, 2017). Dikatakan unik karena proses tumbuh kembang dan masa keemasan (golden age) terjadi secara bersamaan. Oleh sebab itu, proses tumbuh kembang di usia dini sangat mempengaruhi apa dan bagaimana mereka di masa mendatang. Oleh sebab itu, orang tua harus memperhatikan cara mendidik anak mereka dengan cara yang tepat sejak usia dini sehingga anak tumbuh dengan kualitas yang baik. Dikatakan bahwa kualitas anak yang baik dapat tercapai melalui proses tumbuh kembang yang baik juga (Handayani, 2017). Disinilah peran orang tua sangat penting untuk perkembangan emosi, sosial dan kognitif anak.

Pada kenyataanya banyak para orang tua yang belum mengetahui akan pentingnya mendidik atau pola asuh terhadap proses tumbuh kembang anak. Berdasarkan hasil wawancara dengan Anya Cahyaning yang merupakan psikolog pendidikan dan perkembangan anak berpendapat bahwa masyarakat di Indonesia masih melakukan kesalahan dalam mendidik anak dan sudah menjadi kebiasaan karena tidak mengetahui hal yang benar sehingga menimbulkan beberapa masalah pada proses tumbuh kembang anak, seperti menimbulkan emosi negatif dan kenakalan pada anak.

Kesalahan yang sering dilakukan oleh orang tua adalah menggunakan pola asuh berupa kekerasan verbal maupun fisik terhadap anaknya. Kekerasan verbal terhadap anak seperti membentak dan berbicara kasar menyebabkan anak menjadi takut dan menutup diri. Sedangkan kekerasan fisik yang dilakukan orang tua seperti memukul, memberi hukuman yang bukan solusi tepat untuk mengatasi situasi sulit pada anak. Kesalahan tersebut dilakukan secara terus menerus di berbagai tempat dan kalangan. Orang tua tidak mengetahui kesalahan yang telah mereka lakukan akan tertanam di benak sang anak dan menyebabkan terciptanya emosi yang buruk pada anak. Kelak, anak akan menjadi orang yang memiliki sikap "kemandirian defensi" atau defensi independence yaitu seseorang yang acuh tak acuh, tidak butuh orang lain dan tidak dapat menerima persahabatan karena sejak kecil ia mengalami kemarahan, rasa tidak percaya dan emosi negatif lainnya (Megawangi, 2004). Akibat dari ketidaktahuan orang tua mengenai pola asuh yang tepat terhadap anak ini menjadi sebuah permasalahan darurat yang harus diatasi oleh setiap orang. Oleh karena itu, diperlukan sebuah media yang mampu memberikan edukasi kepada para orang tua agar mampu menerapkan pola asuh yang tepat pada anak sejak usia dini.

Buku ilustrasi dipilih sebagai media yang tepat karena buku merupakan media yang paling cocok untuk mengetahui informasi lengkap dan detail. Buku juga bersifat tahan lama sehingga mampu bertahan dan tetap eksis di berbagai kalangan. Selain itu, Menurut Made (Janottama, 2017), ilustrasi merupakan gambar yang menyertai naskah, artikel atau media komunikasi lainnya, sebagai penyemarak halaman pada buku-buku sehingga mampu menjelaskan dengan gambar apabila belum bisa dengan katakata. Oleh karena itu, buku berbasis ilustrasi dipilih karena bertujuan untuk memudahkan mengedukasi para orang tua yang memiliki anak berusia $1-6$ tahun ataupun calon orang tua muda. Hal ini dikarenakan dengan adanya ilustrasi mampu menarik perhatian pembaca dan menciptakan kesan yang mendalam serta memudahkan pembaca dalam mengingat konsep dan gagasan yang ada dalam buku. Dengan adanya buku ilustrasi ini juga bermanfaat untuk mengenalkan ilustrasi dalam kehidupan masyarakat. Sehingga masyarakat mampu mengenal ilustrasi tidak hanya menarik perhatian namun juga terdapat pesan yang disampaikan dalam ilutrasi itu sendiri.

Selain itu, Buku ini bertujuan untuk menyampaikan pesan kepada orang tua bahwa anak yang mereka miliki berhak untuk bahagia dengan mendapat kasih sayang dari orang tuanya dan mendapat masa depan yang lebih baik. Selain itu, memberikan edukasi bahwa peran orang tua sangat penting untuk membentuk karakter anak di masa mendatang sehingga anak mampu mejadi pribadi yang lebih baik. 


\section{Metode Penelitian}

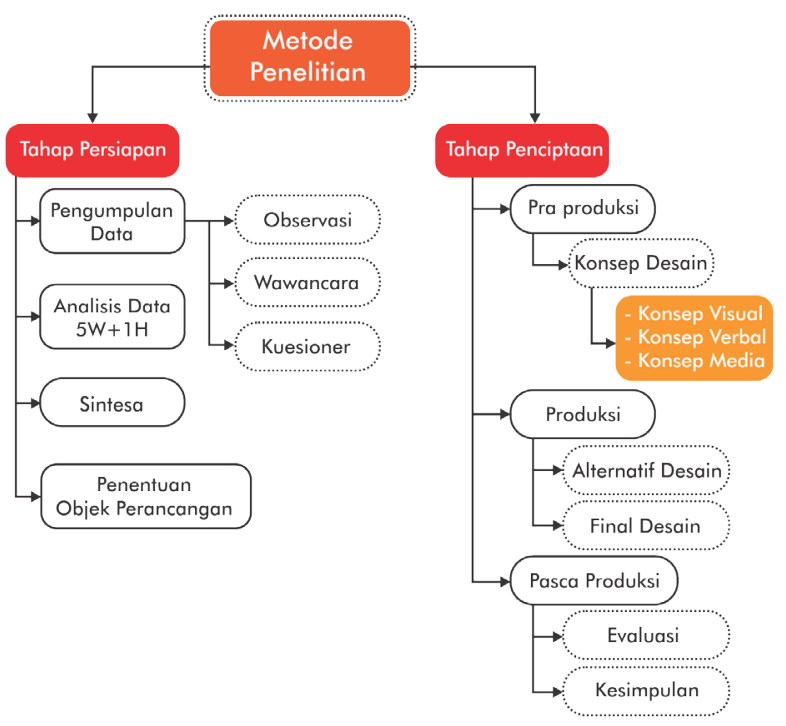

Gambar 1. Metode Penelitian

(Sumber: Dokumentasi Masnuna, 2020)

Pada perancangan ini menggunakan dua tahapan metode yaitu tahap persiapan dan tahap penciptaan. Tahap persiapan terdiri dari pengumpulan data, analisis data, sintesa dan penentuan objek perancangan. Selanjutnya tahap penciptaan terdiri dari tahap pra produksi, produksi dan pasca produksi (Sugiyono, 2018).

\section{Tahap Persiapan \\ Pengumpulan Data}

Pada tahap ini menggunakan metode pengumpulan data kualitatif dan kuantitatif untuk menghasilkan data yang valid. Metode kualitatif merupakan jenis metode yang hasilnya tidak diperoleh melalui prosedur statistik atau bentuk hitungan lainnya (Gunawan, 2013:80). Metode kualitatif didapat dari hasil observasi dan wawancara mendalam. Sedangkan metode kuantitatif diartikan sebagai metode yang menggunakan instrumen peneltian yang bersifat statistik atau dapat dihitung untuk menguji hasil (Sugiyono, 2015) dan didapat dari hasil kuisioner. Observasi dilakukan dengan mengamati perilaku target audiens yaitu orang tua berusia 25 - 35 tahun yang memiliki anak usia 1 - 6 tahun di wilayah Surabaya. Observasi dilakukan secara mendalam untuk mengamati perilaku dan kebiasaan target audiens pada anak, seperti kegiatan apa saja yang dilakukan bersama anak dan kesalahan yang sering dilakukan oleh orang tua terhadap anak. Selain itu, observasi juga dilakukan di toko-toko buku di Surabaya untuk mengamati dan mencari apakah terdapat buku mengenai pola asuh untuk menumbuhkan emosi positif anak.

Selanjutnya, metode wawancara dilakukan beberapa narasumber. Wawancara pertama dengan Anya Cahyaning Tiyarestu, M. Psi. yang merupakan salah satu psikolog dengan fokus kompetensi pendidikan anak usia dini, parenting dan anak berkebutuhan khusus. Pada sesi wawancara ini memiliki tujuan untuk memperoleh informasi data tentang pola asuh yang tepat untuk anak usia dini. Wawancara kedua dengan Zakiyah Sholehah yang merupakan CoFounder, Penanggung jawab dan desainer produk Gulalibooks, serta community builder Qiraatif. Wawancara ini dilakukan untuk mengggali informasi berkaitan ilustrasi dan strategi membuat buku ilustrasi yang tepat bagi orang tua.

Kemudian metode kuantitatif dengan menggunakan teknik kuisioner. Kuisioner disebar kepada 100 responden yang merupakan target audiens di wilayah Surabaya melalui google form. Metode ini bertujuan untuk mencari pendapat pribadi secara langsung dari target audiens mengenai pola asuh anak dan membantu menentukan visual dari perancangan.

\section{Analisis Data}

Proses analisis data pada perancangan ini menggunakan metode $5 \mathrm{~W}+1 \mathrm{H}$. Analisis data dengan metode ini menggunakan kalimat tanya yang dirumuskan dalam $5 \mathrm{~W}+1 \mathrm{H}$, yaitu what (apa), when (kapan), where (di mana), who (siapa), why (mengapa), dan how (bagaimana). Dipergunakan kalimat tanya karena kalimat ini disebut juga sebagai kalimat menggali informasi. Kalimat tanya tersebut mampu membantu memecahkan masalah dan memicu ide-ide serta solusi yang tepat bagi perancangan.

\section{Sintesa}

Sintesa merupakan kesimpulan atau hasil dari analisis data. Hal ini berkaitan dengan keyword dan konsep desain. Proses pencarian keyword akan lebih mudah dengan adanya proses sintesa. 


\section{Penentuan Objek Perancangan}

Objek perancangan yang akan dibuat adalah buku ilustrasi yang bertujuan digunakan sebagai perantara bagi orang tua dalam memahami dan memelajari tentang pola asuh yang tepat untuk menumbuhkan emosi positif anak usia dini.

\section{Tahap Penciptaan \\ Pra Produksi}

Pada tahap pra produksi meliputi penyusunan konsep desain, yaitu konsep verbal, konsep visual dan konsep media. Konsep desain akan dibuat sesuai dengan keyword

\section{Produksi}

Pada tahap ini, perancang akan membuat desain untuk media perancangan. Desain yang dibuat sesuai dengan keyword melalui beberapa alternatif desain hingga final design terpilih.

\section{Pasca Produksi}

Pada tahap ini, akan dibuat kesimpulan dan evaluasi untuk mengetahui kekurangan dan kelebihan perancangan serta harapan untuk perancangan yang akan datang.

\section{Hasil dan Pembahasan}

\section{Target Audiens}

\section{Demografis}

Berusia 25-35 tahun, Unisex (Wanita dan pria), berperan sebagai Ibu dan ayah memiliki anak usia antara 1-6 tahun, calon orang tua, status sosial kelas menengah dengan pekerjaan pegawai swasta dan ibu rumah tangga.

\section{Geografis}

Surabaya dan sekitarnya.

\section{Psikografis}

Sederhana, Suka bergaul, Suka Membaca Buku, Menghabiskan Waktu di Rumah, Memiliki rasa ingin tahu hal terbaik yang harus dilakukan untuk anak, Mementingkan kebaikan anak.

\section{Tahap Persiapan \\ Hasil Pengumpulan Data}

\section{Observasi}



Gambar 2. Foto Narasumber

(Sumber: Masnuna, 2019)

Observasi dilakukan pada seorang ibu di wilayah Surabaya yaitu Devi Kristina yang berusia 28 tahun dan memiliki putri bernama Najwa Cantika Putri yang berusia 3,5 tahun dengan sifat aktif, suka berbicara dan bertanya segala hal yang tidak diketahuinya.

Setelah mengikuti keseharian Ibu Devi sejak bangun tidur hingga kembali tidur. Didapatkan data bahwa para orang tua muda sangat suka bergaul dan bergosip ketika berkumpul. Mengutamakan keinginan anak tanpa melihat apakah hal itu penting atau tidak. Selain itu, Ibu Devi juga masih suka membaca buku disela-sela menjaga anak. Menghadapi anaknya yang sangat aktif terkadang Ibu Devi kurang sabar dan mengedepankan emosinya agar anak kembali diam dan menurut.

Adapun, pengamatan juga dilakukan di toko buku besar di Kota Surabaya. Salah satunya adalah Gramedia Expo dan Big Bad Wolf. Dari pengamatan tersebut tidak ditemukan buku ilustrasi yang dikemas menarik dan mudah dipahami yang khususnya membahas cara mendidik anak untuk menumbuhkan emosi positif anak. Dalam pengamatan yang ada hanyalah buku berbentuk tekstual saja sedangkan buku ilustrasi masih sebatas cara merawat dan menghadapi bayi berusia beberapa bulan 


\section{Wawancara}

a. Anya Cahyaning Tiyarestu, M. Psi. (Psikolog pendidikan anak usia dini, parenting dan anak berkebutuhan khusus).

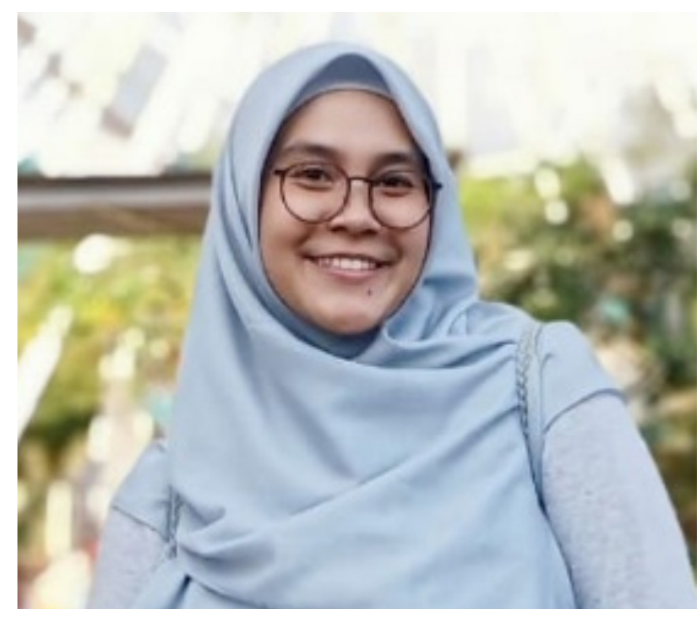

Gambar 3. Foto Narasumber 1 (Sumber: Masnuna, 2019)

Hasil wawancara dengan Psikolog Anya Cahyaning dapat disimpulkan bahwa Pola asuh yang tepat sangat penting karena meskipun anak-anak sudah memiliki tempramen bawaan, anak-anak diibaratkan sebagai kertas kosong dan peran orang tua lah yang mengisi kertas kosong tersebut, akan dibuat seperti apa kertas tersebut. Jadi, mau jadi seperti anak tersebut tergantung bagaimana orang tua mengasuh anak mereka.

Namun, Kesalahan yang biasa dilakukan oleh orang tua adalah mereka merasa paling tahu tentang anak mereka hingga tidak memberi ruang untuk anak lebih mengekspresikan diri, lebih memaksakan kehendaknya sendiri daripada kehendak anak, dan tidak konsisten. Orang tua biasanya tidak konsisten dalam memberi hukuman atau reward pada anak, oleh karena itu lebih disarankan orangtua menggunakan sistem kesepakatan dan konsekuensi pada anak. Orang tua seringkali marah-marah tanpa sebab pada anak, hal ini akan berdampak negatif pada anak karena anak akan menjadi takut dan tidak ingin memulai sesuatu. Anak akan menjadi pribadi yang sulit untuk mengambil keputusan dan mengambil tantangan. b. Zakiyah Sholehah (Co-Founder, Penanggung jawab dan desainer produk Gulalibooks, serta community builder Qiraatif).

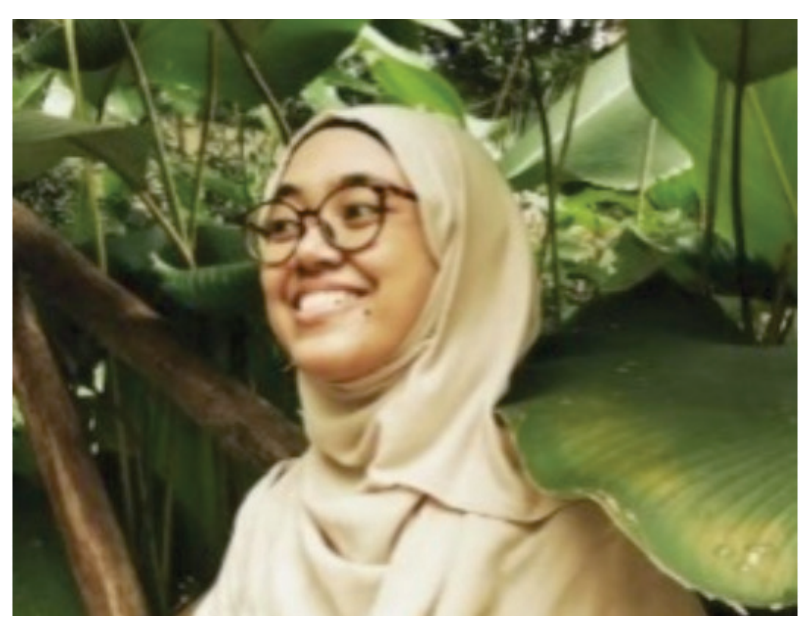

Gambar 4. Foto Narasumber 2

(Sumber: Masnuna, 2019)

Hasil wawancara dengan Zakiyah Shoehah dapat disimpulkan bahwa Buku dengan target orang tua biasanya melihat dari sisi konten dan ilustrasi. Ilustrasi disini dimaksudkan agar mempermudah penyampaian informasi pada target audiens dan menjadi daya tarik tersendiri. Adanya ilustrasi dalam buku dengan terget audiens orang tua tergantung dari tujuan produk, seperti buku praktikal atau how to yang mengutamakan visual sebagai penyampai pesan sehingga ilustrasi sangat penting bagi buku jenis seperti ini. Beda halnya dengan buku sastra yang penulisnya bertujuan agar pembaca berimajinasi maka ilustrasi menjadi unsur yang minor. Sehingga dapat disimpulkan bahwa fungsi dari ilustrasi untuk menyampaikan pesan yang tidak bisa dijelaskan oleh teks amatlah penting.

\section{Kuisioner}

Pada kuisioner yang telah disebar dapat diambil kesimpulan bahwa orang tua jaman sekarang cenderung melakukan kekerasan verbal seperti membentak anak dan sebagainya ketika anak melakukan kesalahan (56\%). Selanjutnya, orang tua meluangkan waktu bersama anak 1 - 2 jam (41\%) dan setuju bahwa keinginan anak harus terpenuhi (70\%). Selain itu, sebagian besar orang tua sangat 
setuju bahwa peran orang tua penting untuk perkembangan anak (91,2\%). Kemudian, orang tua juga setuju bahwa anak sebaiknya jauh dari gadget di usia dini $(86,6 \%)$. Para orang tua juga tertarik untuk mengetahui bagaimana pola asuh yang tepat $(86,4 \%)$ dan lebih tertarik dengan media informasi berupa buku $(75 \%)$ dengan mempertimbangkan ilustrasi (79\%), konten yang menarik (16\%).

\section{Hasil Analisis Data}

Data selanjutnya dianalisis menggunakan metode $5 \mathrm{~W}+1 \mathrm{H}$, yaitu sebagai berikut:

1. What, masalah yang terjadi saat ini. Masalah yang terjadi pada perancangan ini adalah kesalahan pola asuh anak yang berdampak negatif pada perkembangan anak. Orang tua cenderung tidak memerhatikan bagaimana pola asuh anak yang tepat.

2. Why, alasan terjadinya permasalahan. Beberapa faktor yang menyebabkan permasalahan tersebut adalah orang tua belum memahami atau kurang mendapatkan edukasi bagaimana mengasuh anak dengan baik dan tepat sehingga masih banyak terjadi kekerasan terhadap pada anak, baik verbal maupun fisik. Padahal, kekerasan tersebut amat tidak baik karena akan berdampak pada tumbuh kembang anak dan sebagai penentu bagaimana anak tumbuh di masa mendatang.

3. Who, Siapa target audiensnya. Target audiens adalah orang tua dengan rentang usia 25-35 tahun dan memiliki anak usia 1-6 tahun atau juga calon orang tua.

4. Where, Dimana permasalahan terjadi. Demografis dari perancangan adalah Surabaya dan beberapa kota di sekitarnya. Namun, permasalahan tersebut terjadi hampir di seluruh wilayah Indonesia.

5. When, Kapan permasalahan tersebut terjadi. Permasalahan tersebut sudah terjadi sejak lama dan tiap tahun selalu ada kasus mengenai kekerasan pada anak. Namun, perancangan ini membuat buku yang akan dibutuhkan oleh setiap orang tua yang memiliki anak menginjak usia 1-6 tahun dan para calon orang tua yang akan memiliki anak.

6. How, Bagaimana solusi yang tepat untuk permasalahan tersebut. Solusinya adalah membuat media yang dekat dengan orang tua muda yaitu buku yang mengusung konten mengenai cara mengasuh anak dengan tepat. Buku akan dikemas dengan menarik dan informatif menggunakan teknik ilustrasi digital painting yang membantu para pembaca lebih mudah memahami apa yang disampaikan.

\section{Sintesa}

Kesimpulan yang dapat diambil dari datadata yang dikumpulkan bahwa uraian mengenai pola asuh pada anak selama ini dikemas dalam buku bacaan yang berisi rangkaian teks saja. Oleh karena itu, perancangan buku ilustrasi mengenai pola asuh yang tepat ini memiliki inovasi dan diferensiasi dari buku-buku sebelumnya karena berlatar belakang masalah yang berbeda dan apa yang disampaikan pun juga berbeda.

Selain itu, perancangan akan mempsosisikan diri sebagai media informasi yang mengedukasi dan memotivasi serta membantu orang tua dalam mengasuh anak mereka dengan cara yang tepat. Tujuannya untuk mengurangi potensi kenakalan anak hingga mereka remaja atau dewasa dengan alternatif solusi pencegahan agar tidak terjadi kekerasan pada anak. Sehingga anak dapat tumbuh menjadi pribadi yang mampu mengendalikan emosi dan memiliki karakter yang kuat melalui buku dengan gaya ilustrasi yang menarik dan mudah dipahami pembaca.

Agar perancangan ini tepat sasaran maka segala konsep desain dan media akan disesuaikan dengan kebiasaan dan hal-hal yang mampu memberikan pesan pada target audiens. Seperti, pemilihan warna pastel yang bertujuan menggiring target audiens agar mendidik anak dengan sikap yang lembut. Kemudian pemilihan gaya ilustrasi yang menggunakan garis luwes dan melengkung yang mencerminkan karakteristik target audiens yang ramah dan friendly. Selain itu, penggunaan bahasa yang santai dan menggiring agar pembaca tersentuh hatinya yang menyiratkan isi hati dari sang anak.

\section{Objek Perancangan}

Perancangan ini menggunakan media buku ilustrasi yang menjadi perantara bagi orang tua dalam memahami dan memelajari mengenai 
pola asuh yang tepat untuk menumbuhkan emosi positif anak usia dini. Materi yang akan disampaikan dalam buku adalah bagaimana cara-cara meng-hadapi anak sesuai dengan karakter anak serta apa yang boleh dan tidak boleh dilakukan orang tua terhadap anak mereka. Buku akan dikemas dengan menarik dan informatif menggunakan teknik ilustrasi digital yang membantu para pembaca lebih mudah memahami apa yang disampaikan. Informasi yang disampaikan juga menggunakan bahasa yang komunikatif sehingga informasi dapat tersampaikan dengan mudah.

\section{Tahap Penciptaan}

\section{Pra Produksi}

Konsep Desain

Pada tahap konsep desain, hal yang dilakukan adalah pencarian keyword yang tepat bagi perancangan. Setelah melalui beberpa alur pen-carian keyword, dipilihlah keyword yang sesuai dan tepat untuk perancangan yaitu "Kunci MendidikAnakEmas". Keyword tersebut memiliki makna yaitu sebuah jalan keluar atau solusi bagi orang tua dalam mengasuh anak kesayangan pada masa keemasan agar tumbuh menjadi pribadi yang lebih baik dan unggul. Keyword tersebut didapat dari analisis dengan tahapan sintesa dan penjabaran identifikasi masalah, tujuan perancangan, target audiens dan data riset yang telah didapat. Dengan adanya keyword tersebut dapat membantu dalam merancang konsep buku yang akan dibuat.

\section{Konsep Media}

Media yang akan dirancang berupa buku ilustrasi yang bertujuan Memberikan informasi dan solusi agar orang tua tidak mendidik anak dengan cara kekerasan verbal dan fisik terhadap anak. Selain ittu, media buku ilustrasi akan dibuat efektif dan edukatif sehingga orang tua dapat menumbuhkan emosi positif pada anak.

Buku Ilustrasi akan berjudul "Rahasia Menjadi Orang Tua Hebat”. Judul tersebut dipilih bertujuan menekankan kepada orang tua yang ingin menjadi orang tua hebat. Hal ini dapat tercapai apabila orang tua menyadari akan pentingnya mendidik anak dengan hati, yang artinya dengan penuh kasih sayang tanpa adaya kekerasan baik kekerasan verbal maupun fisik. Sehingga dengan judul tersebut mampu menarik perhatian orang tua untuk membacanya.

Konsep media dalam perancangan ini secara sistematis, sebagai berikut:

1. Buku memiliki ukuran $23 \mathrm{~cm} \times 16 \mathrm{~cm}$ berbentuk potrait.

2. Memiliki judul "Rahasia Menjadi Orang Tua Hebat" dan sub-judul "Tips Menumbuhkan Emosi Positif Anak".

3. Bahan yang digunakan adalah kertas HVS $100 \mathrm{gsm}$ dan dijilid softcover.

4. Cover depan menggunakan karakter keluarga dengan ekspresi gembira guna menggambarkan kebahagiaan dan dicetak Spot UV pada judul agar terdapat tekstur pada buku.

5. Berisi tentang bagaimana mengenali dan menangani sifat anak serta hal-hal yang harus dilakukan dan tidak boleh dilakukan orang tua terhadap anak, khususnya anak usia golden age.

6. Cover belakang terdapat sinopsis buku.

7. Penjualan buku dilakukan secara online dan secara langsung berada di toko-toko buku ternama seperti Gramedia, Uranus, dan Togamas di beberapa kota.

8. Publikasi buku akan dilakukan di media online dengan bantuan dari komunitas-komunitas parenting yang ada di media sosial seperti instagram dan facebook. Selain itu, buku ini juga akan memiliki akun instagram sendiri sehingga memudahkan masyarakat jika mencari buku mengenai pola asuh ini.

Adapun konten/ isi buku, sebagai berikut:

1. Cover Depan

2. Cover Dalam

3. Halaman Pembuka

4. Prakata

5. Daftar Isi

6. Isi

- $\quad$ Peran Ayah dan Ibu

- $\quad$ Tipe Kepribadian Anak

- Sanguinis

- Koleris

- Melankolis

- Plegmatis

- Jenis-Jenis Pola Asuh

- Otoriter

- Permisif

- Otoritatif 
- $\quad$ Apa yang harus Dilakukan Orang Tua?

- Anak Usia 1 - 2 tahun

- Anak Usia 2 - 3 tahun

- Anak Usia 3-4 tahun

- Anak Usia 4 - 5 tahun

- Anak Usia 5-6 tahun

7. Halaman Penutup

8. Profil Penulis

9. Daftar Pustaka

10. Cover Belakang

\section{Konsep Verbal}

Pada perancangan buku ilustrasi tentang pentingnya pola asuh yang tepat untuk menumbuhkan emosi positif anak menggunakan gaya bahasa yang ringan, santai dan mudah dipahami oleh target audiens. Kemudian, metode penyampaiannya juga santai dan interaktif dengan memberikan kalimat tanya pada pembaca, sehingga pembaca akan diajak berpikir atau merasakan apa yang sedang disampaikan dan mampu menambah keterhubungan antara pembaca dengan buku. Buku ilustrasi ini juga ditambah dengan adanya quotes seputar keluarga yang mampu mengena di hati para pembaca, karena berisikan tentang suara-suara hati atau kata-kata motivasi untuk orang tua.

\section{Konsep Visual}

\section{Ilustrasi}

Ilustrasi yang dibuat pada perancangan buku ini yaitu menggunakan ilustrasi dengan garisgaris yang luwes dan melengkung sesuai dengan keyword. Pembuatan ilustrasi berdasarkan referensi yang sesuai dengan target audiens. Setelah memiliki referensi dan rujukan pembuatan karakter keluarga diambil sampel dari foto keluarga yang kemudian didigitalkan dan merujuk pada keluarga tersebut.

\section{Tipografi}

Tipografi dalam perancangan buku ini menggunakan prinsip readability dan legibility. Selain itu, menggunakan typeface yang memiliki garis luwes dan melengkung yang me-ngesankan ramah, lembut dan penuh kasih sayang. Typeface yang digunakan pada pe-rancangan buku ini sebagai headline yaitu Chocolate Valentine. Typeface pada sub headline menggunakan kiddos dan typeface pada body text menggunakan dosis yang juga memiliki karakter berujung rounded dan mudah terbaca.

\section{Warna}

Warna yang digunakan mengacu dengan keyword dan karakteristik dari audiens yang ramah dan friendly. Setiap warna mampu memberikan efek psikologis tertentu bagi manusia secara mental dan emosional (Sandhi, 2013). Oleh karena itu, warna pastel dijadikan acuan warna dalam perancangan karena dinilai mampu menggiring orang tua untuk bertindak lembut dalam mengasuh anak. Warna pastel yang diambil mengacu dari penggambaran kehangatan atau kasih sayang dan juga kebahagiaan.

4. Layout

Layoutyang akan digunakan akan menekankan ilustrasi dibanding dengan tulisan sehingga fungsi dari ilustrasi sebagai penggambaran teks dapat diterapkan. Selain itu, layout akan dibuat dengan komposisi asimetris yang abstrak, bebas dan fleksibel dengan konten yang akan disampaikan. Namun, tetap menerapkan prinsip-prinsip layout seperti, sequencel urutan, Emphasis/ penekanan, balancel keseimbangan dan unity/ kesatuan.

\section{Produksi}

\section{Alternatif Desain}

\section{Karakter}

Pembuatan karakter keluarga diambil sampel dari sebuah keluarga muda yang memiliki seorang anak berusia antara 1-6 tahun. Karakter yang diambil adalah karakter keluarga yang harmonis dan bahagia serta mencerminkan kehangatan dalam keluarga.
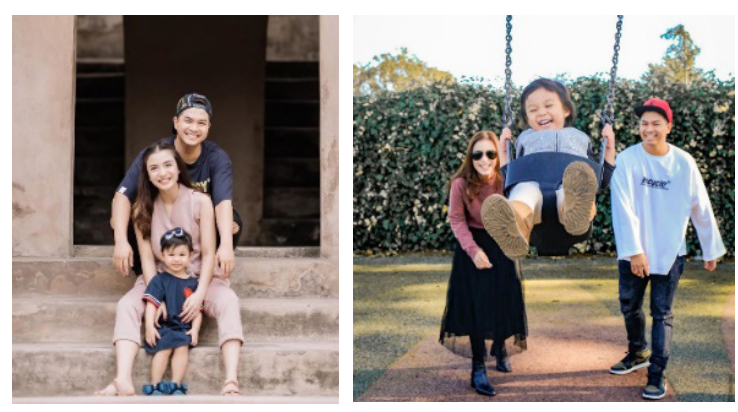

Gambar 5. Acuan Keluarga Terpilih 63\% dalam kuisioner

(Sumber: https://instagram.com/chelseaolivia, Diakses pada 13 Februari 2020) 
Alternatif karakter dibuat berdasarkan referensi yang sesuai dan sering dilihat oleh target audiens.

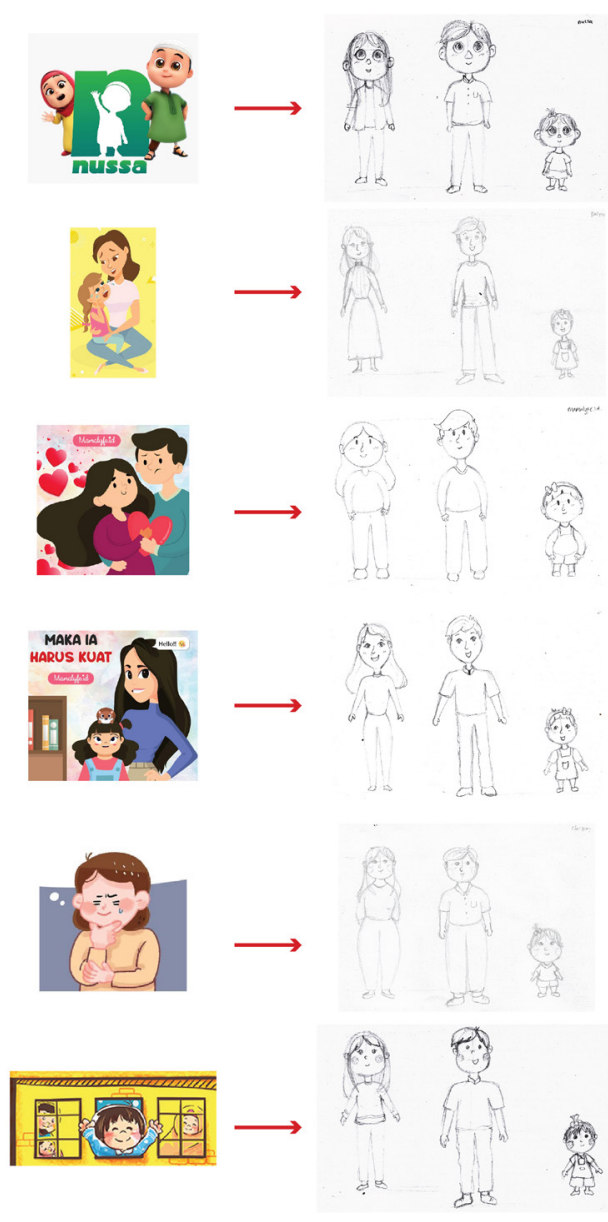

Gambar 6. Alternatif Karakter (Sumber: Dokumentasi Masnuna,2020)



Gambar 7. Karakter Terpilih

(Sumber: Dokumentasi Masnuna, 2020)

Dari beberapa alternatif tersebut terpilih satu alternatif yang kemudian diproses dalam bentuk digital seperti pada gambar 7 .

\section{Cover}

Setelah karakter terpilih maka proses pembuatan cover dimulai. Beberapa alternatif cover pada perancangan ini dapat dilihat pada gambar 8.

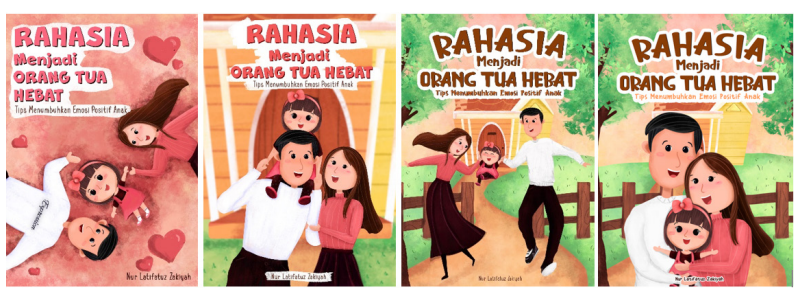

Gambar 8. Alternatif Cover

(Sumber: Dokumentasi Masnuna, 2020)

\section{Final Desain}

Setelah beberapa alternatif telah dipilih, maka selanjutnya proses layouting buku sesuai dengan desain yang telah ditentukan.

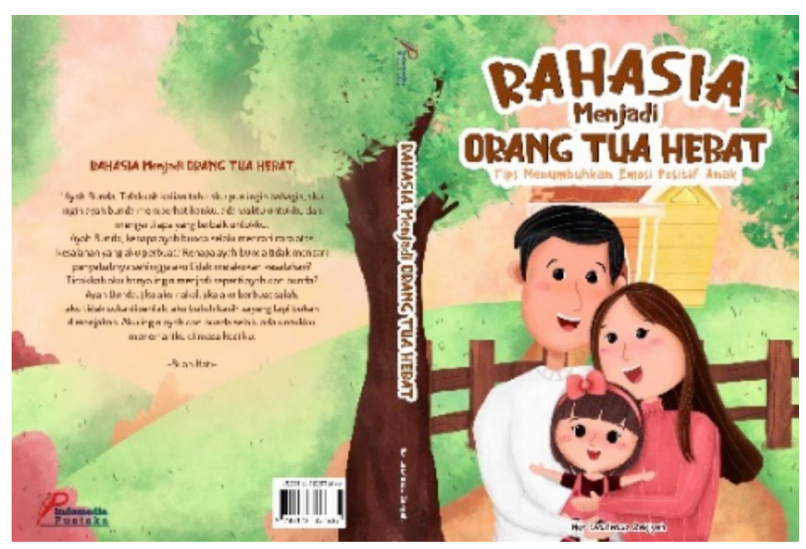

Gambar 9. Final Cover

(Sumber: Dokumentasi Masnuna,2020)



Gambar 10. Final Isi Buku

(Sumber: Dokumentasi Masnuna,2020) 


\section{Pasca Produksi \\ Simpulan}

Buku ilustrasi "Rahasia Orang Tua Hebat" ini dirancang dengan tujuan sebagai pedoman dan pendamping bagi para orang tua muda dan calon orang tua dalam mendidik anak usia dini. Dengan adanya buku ini para orang tua dapat menilai apakah yang dilakukan pada anak sudah benar dan berdampak baik atau tidak. Selain itu, orang tua akan mendapat edukasi bahwa yang terpenting dalam mendidik anak adalah perihal mengetahui isi hati anak, solusi bagaimana anak tumbuh dengan emosi positif dan dapat mengendalikan emosi negatifnya. Semua akan dijelaskan dalam buku sesuai dengan jenjang usia anak yaitu $1-6$ tahun. Sehingga buku ini dapat memudahkan para orang tua dan mengontrol diri untuk menghindari perilaku-perilaku negatif yang berdampak buruk pada anak.

\section{Evaluasi}

Buku ilustrasi ini masih memiliki kekurangan dalam hal konten karena buku ini sangat kompleks dengan membahas hal yang harus dilakukan dan tidak boleh dilakukan orang tua di tiap jenjang usia yaitu usia $1-6$ tahun. Diharapkan untuk perancangan selanjutnya terdapat tematema yang berkaitan dengan anak usia dini agar menambah edukasi bagi para orang tua dengan media-media yang lebih dekat dan interaktif bagi orang tua.

\section{Kepustakaan}

Amrillah, H. M. T. (2017). Memahami Psikologi Perkembangan Anak Bagi Pengembangan Sosial Emosional Anak Usia Dini. AnNahdhah, 11(2), 90.

Gunawan, I. (2013). Metode Penelitian Kualitatif, Teori Dan Praktik. Bumi Aksara.

Handayani, D. S. (2017). Penyimpangan Tumbuh Kembang Pada Anak Dari Orang Tua Yang Bekerja. Keperawatan Indonesia, 20(1), 48-55.

Janottama, I. P. A. (2017). Gaya dan Teknik Perancangan Ilustrasi Tokoh pada Cerita Rakyat Bali. Segara Widya, 5, 25-41.

Megawangi, R. (2004). 10 Kesalahan Orang Tua \& Guru Dalam mendidik dan solusinya. ANNAJAH PRESS.
Sandhi, B. (2013). Analisis Kualitas Hasil Praktik

Desain Sulaman Berwarna Pada Mata Kuliah Desain Hiasan. Pendidikan Kesejhateraan Keluarga, 3(2), 43.

Sugiyono. (2015). Metode Penelitian Kombinasi (Mix Methods). Alfabeta.

Sugiyono. (2018). Metode Penelitian Kuantitatif,Kualitatif dan R\&D. Alfabeta. 